\title{
Urban Identities and Belonging: Young Men's Discourses about Pikine (Senegal)
}

\author{
Sebastian Prothmann
}

\begin{abstract}
Suburbs in many parts of the world fall victim to discriminating assessments from the outside. Pikine, an urban area within the Dakar region of Senegal, which was one of urban Africa's major government restructuring projects, is no exception. The frequently evoked and generalised narratives of urban lifeworlds often fail to describe the heterogeneous characteristics of neighbourhoods in precarious large agglomerations throughout the world. In particular, the youth in this urban quarter are important drivers of economic growth and means with which to combat poverty and strengthen social cohesion. This chapter, based on 11 months of ethnographic fieldwork in Pikine between 2011 and 2013, will illustrate how resourceful young men organise their lives. On the one hand, they have equipped themselves with distinct identities and switch them depending on the situation. On the other hand, they have resurrected their feelings of solidarity, courage and local pride in the notion of Pikinité as a 'self-revaluationstandard'. Because of increasingly precarious realities and rising unemployment, individualistic tendencies - combined with the aspiration of self-realisation-have gained ground and challenge these stratagems.
\end{abstract}

African urban agglomerations are mostly analysed through the narrow lens of developmentalism, which tends to focus only on lack, making them appear 'as imperfect, stunted, and underdeveloped versions of what they ought to be' (Myers and Murray, 2007, 10). These agglomerations come up short if indicators from the global North are applied (Myers, 2011). Also, if the overlapping interconnections of different cities in the world were taken into account, the analyses would look very different (Robinson, 2011). Therefore, alternative readings of the African urban cityscape can help us understand urbanity in all its diversity and productivity by taking the power of disorder into consideration (Myers, 2011).

(C) SEBASTIAN PROTHMANN, 2018 | DOI:10.1163/9789004387942_012

This is an open access chapter distributed under the terms of the prevailing CC-BY-NC License at the time of publication. 
When reading urban Africa, we also have to be aware of its huge youth population that is trying to make a living within unfavourable and limited socioeconomic structures (Honwana, 2012). This population, which only faces murky prospects of finding work in these inequitable, growing towns, primarily has access to informal structures (the informal employment market, informal property rights, informal transport, etc.). However, for a long time, urban spaces in Africa functioned as 'integration machinery', offering work for graduates of formal education, often in the public sector, although opportunities here have declined. Youth of today, though comprising a much higher proportion of graduates of formal education, are exposed to various forms of marginalisation, exclusion and lack of work. Thus, young people are emerging as a new social group whose common characteristic is that of social deprivation. Because of this, new ways of dealing with problematic situations are also emerging, and these are not necessarily linked with the social expectations of society.

In the 199os Bayart et al. (1992) posited that young people had shown a great willingness to oppose political regimes but that their power had not sufficed to achieve political revolution. For this reason, assumptions long circulated about the 'lost generation'-weak, marginalised youths debarred from political decision-making processes (Cruise O'Brien, 1996). But earlier the historian Mamadou Diouf had emphasised the pivotal role of the youth (1992; 1996; 2002). In 2018 after the Arab Spring, which has essentially been described as a youth rebellion, and the 'awakening' of urban youth before and during the 2011 elections in Senegal, the power of the young needs rethinking. Nonetheless, in postcolonial debates youths are still viewed as the epitome of both violence and change. If they are, on the one hand, interpreted as offering great hope for the future, on the other they are seen as agents of government instability and protest (Benga, 2001; Diouf, 2003; Durham, 2004). Scholars working on youth have stressed the heterogeneity and ambivalence of youths, depicting them as 'vanguards' and 'vandals' (Abbink and van Kessel, 2005, 22), as 'makers' and 'breakers' of society (de Boeck and Honwana, 2005, 2) or as being 'between Jerusalem and Babylon' (Benga, 2001), drawn from taxonomies between recognition and disparagement.

In general, youth in Africa cannot be determined as a biological entity. They are a cultural construction (Honwana, 2012), one that might easily encompass people who are thirty or even forty years old (Baller, 2010). Youth is, moreover, a fluid category that depends very much on historical, social, cultural and political circumstances (Baller, 2005b). The perception of youth as a time of transition, a constituent element of the concept of youth itself, hinges on the idea of a move from a period of dependency (mainly within the family unit) to the 
attainment of financial independence through a fixed job and the beginning of one's own family. In the precarious financial context of urban Senegal there is much concern regarding delayed entry or possibly even the impossibility of entry into the labour market. This refused entry and other complications entail a prolonged phase of waiting, resulting in a complex interplay of negotiations between social realities and representations (Baller, 2010).

Based on 11 months of ethnographic fieldwork in the neighbourhoods of Wakhinane II Quartier Mballo Der and Sadio Guissé (Guinaw Rail Nord) in Pikine, a city in the département (administrative district) of Pikine within the Dakar region of Senegal, this contribution examines the strategies that young urban men use to deal with their marginalisation and with globalisation. The empirical data will give insight into how young men oscillate between different identities and negotiate urban and religious belongings and thus live urbanity in a productive way. The research shows how local youth in unsteady everyday lifeworlds display their inventiveness by creating stratagems with the help of refined techniques that permit them to cope with constraints and to weave new ideas of being and becoming into their lives. In a broader perspective, this chapter attempts to tackle the question of how young men in the global South approach issues of belonging and identity creation in a globalised world.

For many people, a symbol of the failure of Abdoulaye Wade's regime is the fifty-two-meter-tall bronze statue in socialist realist style that is highly visible from different parts of the Cap Vert Peninsula. Perched on top of one of the Collines des Mamelles, the twin hills in the suburb of Ouakam, geographically the westernmost point of Africa's mainland, overlooking the Atlantic Ocean and dominating the horizon of Dakar, the statue depicts a family: a muscular, half-naked man with broad shoulders and six-pack abdominals holds a nude baby and points resolutely ahead, accompanied by a woman wearing a short skirt. The statue is about half a metre taller than the Statue of Liberty in New York and as such is the tallest sculpture outside of Asia and Eastern Europe (Roberts, 2013). It was meant to symbolise Africa's rebirth after centuries of slavery, colonialism and political domination from the outside (Grabski, 2017). Interestingly, according to official publications from the Senegalese government, the African Renaissance Monument cost nothing. It was built by a company from North Korea (Mansudae Overseas Projects) in exchange for a prime area of land belonging to the Senegalese government (Ritter, 2011). But rumours of a cost of USD 27 million (Arieff, 2012) have provoked a huge controversy on 
the extravagant and wasteful use of state finances on high-profile architectural and urban projects (Grabski, 2017). It is also alleged that ex-president Abdoulaye Wade claims 35 per cent of the entrance fees to the statue's interior and its museum.

However, in spite of its original intention to mark the rebirth of the continent and to point towards a bright future, in reality little has changed: decay, mismanagement, nepotism, corruption and poverty still abound in Senegal (Gilley, 2010; De Jong and Foucher, 2010). Emblematic of Wade's vision of modernity and the nation and his strategic alignment with foreign investors, the monument therefore represents for many people the 'disjuncture between governmental initiatives and on-the-ground crisis in infrastructure' (Grabski, 2017, 198). It is a glimmering daily reminder of state failure, especially the squandering of public funds and the preferential treatment afforded to select areas of the city.

The Sopi ${ }^{1}$ election campaign of Abdoulaye Wade in 2000 was perceived as a watershed moment by young people all over Senegal. Although he was almost seventy-four years of age during the election campaign, he succeeded in connecting with the youth of the country. His campaign events were attended by masses of young people. His unctuous speeches, which focused mainly on employment, were warmly welcomed by young people tired of forty years of the inefficient economic policies of Senegal's socialist government. Many youth felt as if Abdoulaye Wade took the words right out of their mouths. He styled himself as their saviour, able to make their biggest unfulfilled wishes come true, by promising universal access to education and greatly increased chances of becoming productive members of society. The time of sitting around passively, drinking endless cups of àttaaya (a sugary green tea), was supposed to come to an end. He painted a very rosy picture of Senegal as an emerging country, depicting the youth as the most important actors of his promoted politics of sopi (change). Thus, he directly addressed young people's profound lack of societal recognition and self-worth, which was caused by their lack of integration into society due to widespread unemployment and resulting poverty (Sene Absa, 2011; Nelson, 2014; Osmanovic, 2017).

Wade succeeded in creating a feeling of 'legitimate expectation' (Ferguson, 1999) that the precarious situation of the youth would improve, and a feeling of hopefulness and optimism soon spread among Dakar's youth. After his interventions failed to pay off for the young generation, his former supporters

1 Sopi literally means 'change' and was used as a strategy to transform Senegal. 'Change' encompassed a complete remaking of political as well as the moral standards of Senegalese society. 
felt betrayed. These youth had grown up with higher expectations due to his populist speeches, but after some years the majority of them still did not have steady jobs. They grew increasingly frustrated and fed up with the government, and they talked of an unsuccessful deal (Sene Absa, 2011) and of broken hopes. In January 2011, one year before Abdoulaye Wade confirmed that he planned to run for a third term, artists, intellectuals and activists created the movement Y'en a marre ${ }^{2}$ (had enough).

Economic redemption was partly translated into large-scale public works ${ }^{3}$ mostly funded by foreign capital, but it failed to impact the masses, especially the still-marginalised youth. Wade's concentration on private sector investment in infrastructure instead of in education and social programmes left the young population at the mercy of the neo-liberal free market, in contrast to the forty years of government by the Socialist Party of Léopold Senghor (196o-80) and Abdou Diouf (1981-2000) (Galvan, 2001). On the one hand, Wade's interventions were inflected by globalisation, and he focused on the 'construction of professedly globalized spaces of consumption and circulations [...] detached from histories and shared struggles of the past decades' (Melly, 2013, 386) with the help of foreign expertise, capital and international organisations. On the other hand, he engaged in constructing physical manifestations of nationalism in Dakar, such as the Millennium Gate and memorials like the statue Demba and Dupont, where a Senegalese infantryman beside a French soldier symbolises the support of Senegal for France during World War II (Diop, 2012). Wade's government's negligence of the periphery across its large-scale urban projects was striking, as was its overlooking of the economic heart of the capital, the Plateau (Grabski, 2017). ${ }^{4}$ The Plateau's architecture, which for a long time was redolent of southern France, had become more and more dilapidated, and today it is suggestive of a neglected urban quarter in France to the European

2 Y'en a marre is a collective comprising members of the civil society, rappers such as the Kaolack rap duo Keur Gui, Fou Malade, Simon, and Djily Bagdad, among others, and journalists, particularly Fadel Barro. In January 2011 it was launched to oppose political developments, especially around the despotic arrangements of incumbent Abdoulaye Wade. For further information see Savané and Sarr, 2012; Prause, 2012.

3 Projects included the construction of multistorey buildings, roundabouts, ramps and tunnels, which became signs of the modernisation of the city of Dakar. This vision of Abdoulaye Wade's modernisation was crowned by the construction of the Dakar-Diamniadio toll highway and the new airport Blaise Diagne International Airport in Diass, as well as the renovation of the Corniche Ouest (Diouf and Fredericks, 2013).

4 With the construction of new government buildings, museums and monuments, the Plateau was the heart of the postcolonial capital after independence and was shaped by Senghor's idea and vision of postcolonial nationalism and his literary and ideological trend of Negritude (Melly, 2013). 
observer. With its throbbing market, Sandaga, at the end of the Avenue Georges Pompidou, referred to as Ponty, and its banks and service companies around Independence Square, the Plateau serves until today as the main artery of daily life in Dakar. The street markets and shops here, which are mostly in the hands of religious brotherhoods, were completely absent in Wade's 'soaring oratory about economic emergence' (Melly, 2013, 393) and modernisation.

Many people in Pikine expressed frustration at Wade's exclusive focus on streets and populations in Dakar and his relative neglect of Pikine, which produced further inequalities rather than eradicating them. Furthermore, numerous rumours circulated asserting the embezzlement of resources by Wade's government and the enrichment of plutocrat ministers who siphoned off resources of all sorts. While the political and economic elite enjoyed wellmaintained infrastructure along the Corniche and in the neighbourhood of Almadies, the average citizen continued to face an unpredictable future in flood-prone and neglected neighbourhoods with ailing infrastructure and ramshackle houses.

Even today, the glittering manifestations of aggressively promoted modern and globalised 'materiality' scattered throughout the city in the form of new infrastructure, new residential areas, modern supermarkets and other shopping facilities, new gas stations, fast-food restaurants, night clubs, leisure facilities, and so on serve as a constant reminder that the fruits of progress are reserved for a lucky few. When an individual enters Dakar from Pikine via Castor, he or she passes the clean showrooms of Emg Universal Auto (Voitures de Prestige, Americains, Allemandes), which display luxury cars in pristine condition. Transnational connections and longings are also symbolised by commercial booths with painted signboards sponsored by international companies. This signage is part of Dakar's own 'language' (Guibbert, 1983). Barbers, garnished with photographs and painted images of bald heads from $5^{\circ}$ Cent, $2 \mathrm{Pac}$ and other African-American celebrities, and with mural paintings and sophisticated, colourful glass paintings (so-called suweer) featuring portraits of famous religious persons, also contribute to the sensory regime of this cluttered 'urban cacophony' (Mustafa, 2001, 49) that shapes a landscape of global and religious longings. Despite their visual prominence, these urban facets are not representative of the experience of the majority of the population of the Dakar region. Or, as Jean and John Comaroff said, here 'the millennial moment has passed without a palpable payback' $(1999,284)$. The incoming 'neo-liberal logics of global capital flow' (ibid, 396) that shaped Wade's vision of the city's future, and thus that powered the relocation of global city allure from the Plateau as a statement of the post-independence time to the Corniche and Almadies, can also be seen as a brusque rejection of the immediate present with its concrete, 
precarious and known realities, which are not altered in any respect by these futuristic visions.

\section{Pikine, Dakar's Largest Suburb}

The city of Pikine was built in the 1950s, as housing problems became more and more urgent on the Cap Vert Peninsula and slums began to appear in neighbourhoods such as Dakar Fass and Colobane, and as the density of the central neighbourhoods of Médina increased. To curb these phenomena the state eventually decided to relocate illegal residents of these areas to outside of the city, in Pikine (Chenal, 2013), which was created under French colonial rule in 1952 and stood about 13 kilometres away from Dakar on a former military site covered with sand dunes (Baller, 2005a, 2007).

At the outset, the site of Pikine was a vast and remote area that was supposed to serve as a dormitory town for those who were relocated from the shanty towns of inner Dakar. Over time, many people started to settle outside the boundaries of Pikine, resulting in rapid urban growth that soon exceeded urban planning (Baller, 2010). During this time, the majority of investments were focused on Dakar, and Pikine and Guédiawaye were not granted the same opportunities and means (Chenal, 2013). Infrastructure-or more explicitly the absence of it-has therefore always been a serious problem in Pikine, and severe problems with sanitation, unemployment, informal uses of space, rapid population growth and an essentially young population (with 6o per cent under the age of twenty-one by 2004) are characteristic of the city.

While only a few years ago the geographer Gérard Salem saw Pikine as a 'city of nothing' and a city 'without a real history' $(1998,271)$, today Pikine is a vibrant, cosmopolitan satellite town of Dakar, with 1,170,791 inhabitants (estimation for 2015) (ANSD/SRSD, 2015) from a mosaic of different ethnic communities. Pikine is characterised by a diverse conglomeration of formal low-cost housing developments, multi-family abodes, small cement housing blocks and self-constructed multistorey apartment blocks.

\subsection{Pikinité}

The 199os saw, in particular, the emergence of new forms of juvenile selfidentifications. It was during this time that the Bul Faale movement ${ }^{5}$ started,

5 'Bul Faale' was a song, released in 1994 by Positive Black Soul, one of the first hip-hop groups, founded in Dakar in 1989. Bul Faale served as an empowering slogan that can be translated as 
encapsulating the attitude of young Senegalese trying to succeed through effort and work. The most prominent notion for young men in Pikine was Pikinité, a term used to describe a feeling of solidarity.

Pikinité is first and foremost dignity. It is to share your own life and to give everything of you, to respect your locality in all its social and professional classes. It is to know to forget and wish only the progress of your fellows.

LAMINE, ${ }^{6}$ Wakhinane II Quartier Mballo Der

Pikinité reveals the awakening, in young people, of pride, and their identification with their locality. In the past, Pikine's negative reputation proved substantial and persistent, even impacting the attitudes of its residents. But it took local figures to overcome residents' denial of their origin. One of the first people who spread a positive message about Pikine was the wrestler Tyson, the nickname of Mouhamed Ndao, a reference to the American boxer Mike Tyson. Previously, successful artists from Pikine had hidden their origins. Eventually reversing this trend, young men started to develop pride and to use the Pikinois sense of community as social capital. Artists like Ndongo Lô, Pape Diouf and Ive Niang contributed to improving the reputation of Pikine.

Today young people wear T-shirts with slogans such as I love Pikine, AS Pikine, ${ }^{7}$ Deuk Pikine Mo Neex (living in Pikine is cool), Pikine mo xeew (Pikine is on top) and I am from Kinpi, which can be seen as young men's territorial inscriptions on the city (Lefebvre, 1967). On a more local level, namely on the neighbourhood level, the nawetaan soccer clubs convey a strong sense of local connectedness. Pikine also has many wrestlers who participate in làmb bi (traditional wrestling).

Today many young people in Pikine attribute to themselves perseverance, smartness and skills of hustling, locally voiced as esprit banlieue (suburban mind):

'don't worry', in the sense that despite an ongoing economic crisis you have to keep on living, enjoying life and taking it as it is. You have to work hard and progress (Havard, 2001).

6 The names of informants have been changed in order to protect the anonymity of persons who contributed to this study.

7 AS Pikine is a nawetaan football club. In Senegal, youth organised football tournaments during the rainy season (called nawetaanes). The Wolof word nawet translates as 'rain' or 'rainy season'. In its grammatical form nawetaan means 'the one who passes the rainy season'. Initiated in the 1950s, nawetaan championships subsumed all neighbourhood teams. By this, more than 2,000 sports and cultural associations (ASC-Association Sportive et Culturelle) were formed, which involved not only football but also theatre and local social initiatives (Künzler, 2010). 
If you have a suburban mind, you will have many opportunities, you've seen, you can cope with it, good, quickly-done, what. If you have the strength to move forward, you will have a lot of things. You will persevere, what, because we say Bul faale [...], you will have the spirit of coping.

MoussA, Sadio Guissé

Speaking in general, for young men the notion of Pikinité brings the residents of Pikine together. The residents help each other; they are solidaric. Also, though residents face many challenges in terms of lack of infrastructure, difficult access to education and high youth unemployment, Pikine stands out as one of Senegal's most dynamic fronts of urbanisation and as a very active city with popular urban initiatives. Through the term Pikinité, vivid attributions have elevated an urban neighbourhood famous for its bad reputation.

Part of Pikine's wealth is unquestionably its prolific hip-hop scene, mainly in the form of underground hip-hop. This rebellious style actively condemns the poor conditions of Pikine, allowing for the expression of otherwise dormant indignation about an unjust socioeconomic distribution system. Through performative styles, hip-hop provides the youth in Pikine new forms of authority to reinvent and alter their marginal position (Shipley, 2010). The artists GokhBi System featuring Ndongo Lô, Section Jaxanama, Pétaw bi and Nomila featuring Backa have written songs entitled 'Pikine'. These and others, including Pinal Gang, Balvada, Tigrimbi, Wa BMG 44, Matador, Wagëblë, Coalition Niamu Mbaam, J Xaar Under and Sall Ngaary, have contributed to the establishment of a booming local hip-hop scene. Babacar Niang, alias Matador, is one of the most prominent underground rappers in Pikine and a founding member of Wa bmg 44, a hip-hop group hailing from the suburb Thiaroye between Pikine and Rufisque. While performing around the world, he has called attention to the youth of Senegal and the problematic situations faced in its periphery. In 2006 he founded an education centre in Pikine Ouest called Africulturban, which today has about one thousand members and is dedicated to empowering underprivileged youth via a wide range of activities that centre on music production and urban culture.

\section{Hustling, 'Killing Time' and Improvising in Pikine}

As a result of neo-liberal policies and the gradual withdrawal of the state, hustling has become a means of trying to make a living for young men coping with the emerging social dislocation in Pikine. The phrases 'tey yi ni, town 
bi dafa metti' (today, the town is difficult), 'damay gerer' (I'm managing) and 'ñépp dañuy taqale' (everyone hustles) all describe a sentiment best summed up in the Senegalese expression of xoslu. This expression has become an allencompassing term that describes the day-to-day lifeworlds of young men in Pikine. Anthropologist Suzanne Scheld (2008) traces the term back to the English word hustle and the Wolof word xoos (to scratch, to scrape). In 1995, the well-known Montreal-based Senegalese Mbalax ${ }^{8}$ musician Oumar Ndiaye, alias Xosluman, released the album Hoslu. In a personal communication on Facebook, he told me that initially the phenomenon was described by Gambians using the word 'hustle'. He claimed to have wolofised the term as xoslu and used it as an album title, which popularised its use in Senegal. Xoslu describes the socio-economic predicament of male youth trying by all means to make a living. By the same token, the term xosluman, meaning a seasoned struggler, carries connotations of respect and even admiration for an ability to fight one's way through adverse circumstances. It is a very masculine ascription, because the fervour displayed by these men in striving to get by stands in sharp contrast to the helpless passivity of 'effeminate' men in the face of adversity. Xoslu therefore suggests empowerment, achieved through living by one's wits and proudly rejecting dependence. Young men describe their daily resourcefulness with a powerful youth vocabulary that demonstrates that members of this generation in urban Senegal are trying their best to manage their lives in pursuit of a (better) living (Honwana, 2012), and also that they do not give up easily on their hopes and aspirations. The choice of this jargon around fighting, survival, physical pain and anxieties moreover exalts a certain ethos of toughness that allocates valence and meaningfulness to their lives.

In reality, however, there is a paradox: while work is vital for the economic well-being and for the status of an adult in Pikine, many work opportunities are considered to be beneath these young men's social class. Most of my informants considered notions of social class, dignity and their own position in the neighbourhood to be very important when making choices about pursuing certain income-generating activities in Dakar. Thus, behind the narratives of hard work, suffering and hustling, many urban small-scale activities in the informal sector were associated with a lower rank and therefore with failure and non-advancement. And as occupation indexed a certain rank within the social hierarchy, and many young men were assured of sources of income from other

8 Mbalax is syncretic popular music - made world famous by Youssou N'Dour-that combines popular Western music elements with singing in the Wolof language and dances influenced by soul, Latin, jazz, rock and sabar. 
members of the family, or in some cases from family members abroad, many work opportunities were not accepted. Most young men I spoke to considered working as a street seller or doing other menial jobs demeaning, and they often thought that physical labour indicated a backwardness inherent to poor and uneducated people; this work was usually referred to as liggéeyu baadoolo (the work of the poor). However, young people often taunted other young people for being a beugge lo yomb, meaning that they wanted to achieve something or acquire material gain without doing anything for it, dodging responsibilities and hardship (Prothmann, 2017). This tendency resonates with Comaroffian comment on millennial capitalism's 'allure of accruing wealth from nothing' (2000, 313).

One of the most important words among young men was the verb lijjanti, which was used to cope with personal and societal demands. The term describes using shrewd and opportunistic scheming to overcome obstacles. For example, lijjanti was used when speaking about acquiring or 'organising' a certain sum of money at short notice, or about 'arranging' something. With lijj$a n t i$, the end - usually - justifies the means. Or, more precisely, the verb serves to obscure the manner in which the end is achieved. Even though it does not necessarily mean transgressing the boundaries of socially and legally acceptable behaviour, it carries the connotation of cunning. As hidden procurement of financial means, it implies a nifty social negotiation, one that is also made in order to circumvent social obligations of sharing. Politicians and sports stars have contributed to the success of the concept of lijjanti. Especially influential was the conspicuousness of ministers who posed with their new off-road vehicles and pricey villas. These were people who had nothing before entering politics. Young people started to claim that 'Xaalis ken du ko liggéey danu koy lijjanti' (money is not gained by the fruit of labour, but by resourcefulness). In a newspaper interview, the psychologist Lahbib Ndiaye characterises the Senegalese as people who want to get rich, but who do not want to put any effort into it. He speaks of the philosophy of kheweul (godsend), of coup (trick), of wërsëg (chance) and of 'Yàlla waxul kenn dara' (only God knows what will happen tomorrow). According to him, this philosophy does not embolden individual efforts or recognise the value of work. He quotes histories of fake visas, magical fructifications of businesses and the Senegalese conviction that one can get rich because of a marabout's prayers and occult forces (Le Soleil, 2010).

I also frequently encountered the term nandité among young men. With this, young people voiced various forms of intelligence, pointing out people who know how to cope with life. Nandité normally refers to a Boy Town or a 
'gentleman' who both represent a connoisseur: a young man who is clever, well informed, and who knows how to cope with life and is able to manage. He is an urban citizen capable of projecting an image of success. This includes a certain degree of independence and the ability to manage things on one's own. Furthermore, nandité status can also be achieved in relation to the female sex-in this regard, a nandite is somebody who is able to go on dates with beautiful young women, which is considered to be very costly and demanding.

The expressions ruse and muus indicate the use of savvy tactics to generate financial gains. Many young men in Pikine tried to survive with téq deal in an informal economy. Commodities sent by relatives were often hawked, or articles were bought and immediately sold in an attempt to make a quick profit by inventing stories about the article. As such, articles like laptops or mobile phones can be seen as assets that can be expeditiously sold. This makeshift economy of barter deals can be found among many young males in Pikine. Some of them have developed refined tricks and networks connecting them to the 'right' people; they call themselves téqat deal (makers of deal) and use their connections to make a considerable profit by huckstering commodities of inferior quality. During a night interview with an informant in Médina, my interlocutor did not mince matters; he spoke of the cunning stratagems of young men, leaving the specifics of such techniques fuzzy: 'No, but that's it. They rip off. They are scammers. (...) Or they have a brother or a father who is in Europe, who sends materials and they sell them. Most people are like that'. It is through these techniques of hustling that many young men try to navigate through volatile informal economies in order to make a living.

Walking through Pikine, I was often astonished to see young men and women dressed up very fashionably but not holding any formal employment; I wondered where the financial means for these clothes might derive from. As most people were reluctant to admit what they did for a living or felt ashamed to admit that they received financial support from their families, I was not able to gather sufficient data in response to this question. The frequent disguise of income-generating activities also contributed to this vagueness. In any case, most of these strikingly dressed young men spent the whole day among their circle of friends and acquaintances, doing nothing more than talking, sometimes with humorous mischievousness, and eyeing girls walking along the unpaved roads. They sat on makeshift chairs, sharing roasted groundnuts and drinking tea. Young men referred to this as rey temps bi or kill temps bi (killing time) (Ralph, 2008). 


\section{Pikine and the Baay Faal Identity Among Young Men: Contrasting Visions}

Many young men I met in Pikine blindly admired Baayfaalism, a type of a mendicant suborder of the Murīdiyyah brotherhood ${ }^{9}$ and its sheikhs. For young people, torn between their own expectations and those of their kin, ensnared in fickle and problem-ridden secular lifeworlds of reneged promises, the Murīdiyyah and especially Baayfaalism, becomes a rewarding collective identity, based on a glorious past and offering a clear conception of the world and a positive vision of the future. Baayfaalism allows young men to express their religious identity through a 'rudimentary understanding of a "Muslim life"' (Simone, 2010, 148), simplifying for them the concept of a godly life and bolstering their self-esteem.

Thus, among young men the category of the Baay Faal becomes a vessel for aspirations towards goodness. Following the unwritten laws of harmonious outward representations, young men in Pikine display characteristics such as patriotism, sympathy and openness towards other persons, modesty, nonconsumerism, humbleness, industriousness, cunning, independence, spirituality, respect and solidarity. Baayfaalism can be considered a moral guide that shepherds young males through the 'ambiguity-filled dilemmas of everyday urban life' (Simone, 2010, 145) and as 'synonymous with personal quest, inner improvement and renunciation, and love of God' (Popovic and Veinstein, 1996, 9). Baay Faal morality re-establishes individual agency and further provides the individual with a meaningful and morally unobjectionable identification.

Baay Faal adherents experience recognition among their peers. Thus, being a Baay Faal means being someone, having a social role and especially being a man of God. A Baay Faal is also authorised to take on menial jobs, liggéeyu baadoolo. All this is considered as the opposite of an individualistic, urban version of the self in inner Dakar, which is characterised by a sense of superiority and a blasé attitude. Thus, among marginalised, unemployed young men who hanker for positive change, affiliation to Baayfaalism appears as an emancipating force and enjoys great popularity (Pezeril, 2008). Xavier Audrain (2004) writes that Baayfaalism provides the sense of an alternative moral economy where young men can find their place.

9 Sufi refers to Sufism or in Arab tașawwuf, which is 'the generally accepted name for Islamic mysticism' (Schimmel, 2011, 3). In Senegal the Sufi orders (turuq) the Tijāniyyah, the Qādirīya, the Murīdiyyah and the Layennes are commonly associated with Islam. In total 92 per cent of Muslims are said to be affiliated with Sufi brotherhoods (Pew Research Center, 2013). For a presentation of these brotherhoods see Mané, 2012, 7-22. 
Tshikala Kayembe Biaya (2001) talks of a 'geography of pleasure', referring to tourist sites on the Senegalese coast and certain Dakarois nightclubs. He asserts an emasculation of young men, especially concerning their virility. On the other hand, young women, well aware of their own value in this economy, in which shallow appearances and sexualities prevail, know how to exploit this situation for their own benefit, resulting in economic and sexual frustrations among young men. In this economy of appearance, social status is in a Bourdieuian sense an economic variable. Thus, to conceal the humble realities of destitution, profits of any kind are immediately invested in what the Senegalese label the paraitre ([sag] appearance), which actually hampers opportunities for sustainable accumulation.

The Boy Town like the ease. They don't like to work. They consider themselves as children from, they behave like Parisians, like rich people.

LAYE, Wakhinane II Quartier Mballo Der

This excerpt from an interview shows the negative perception that my Pikinois informants had of this term. The Boy Town is seen as lazy, as a cosmopolitan who knows European etiquette and as a rich person who has had everything handed to him on a silver platter. However, many young men I talked to valued particular characteristics of Boy Town culture, such as having access to luxurious nightclubs, casinos and expensive restaurants in the most sophisticated parts of town. By identifying with these places, the individual transforms himself from an inhabitant of a dilapidated suburb to an inhabitant of a 'hedonopolis' or a 'city of joy' (Ndjio, 2007, 104). This underscores the youth's notion of modernity, as these lifestyles are considered to be progressive (Bahi, 2010). Many of Pikine's youth go to these places, yielding to the temptations of a world of conspicuous consumption and practicing beugge addina (living life to the fullest). This life involves going out, enjoying nightlife in discotheques and bars, eating in restaurants, consuming fast food, and so on.

The Boy Town therefore also counts as a prime example of the individualism à la sénégalaise. In lieu of family and neighbourhood solidarity there is a new, though partially hidden, attitude of bopp-sa-bopp (everyone for himself), a tendency of 'possessive individualism' (Macpherson, 1962) proffered by the neo-liberal regime, infused with values that come from the outside and turn antiquated values upside down. These individualistic tendencies point in the direction of self-realisation and stand in conflict with community- and familyoriented values. The result is expressed in the phrase 'kenn talatul sa mbokk' 
(nobody has time for neighbours). This can be seen as an adaptation borne from circumstances where urban lifeworlds harshly limit the realisation of solidarity and masculine ideals in the conventional sense. Such circumscription stimulates the formation of a 'singularized, autonomous manhood' (de and Plissart, 2006, 244), which stands in opposition to the identity of the socially responsible male who contributes to a wider social network, such as a kinship network.

However, when asked to characterise Pikine, young men generally refer to solidarity rather than to the individualism often displayed in residential areas and middle-class neighbourhoods. Solidarity thus seems to be highly regarded, although it is mostly displayed when ulterior motives are at play, such as for purposes of personal gain. Nevertheless, it is a prized trait, and visible violation of solidarity norms is viewed unfavourably. Far too often the notion is reduced to antiquated customs around lekk (eating) that hold that a guest always eats, regardless of which household they enter. Despite this, solidarity is frequently regarded as the basis of everything and as a value exclusive to Pikine:

You know, the difference made between us, we the suburbanites and they, that's the difference. We, we have solidarity. And I assure you, from now to any time, if you enter a household and you want to eat, you eat. We don't ask for money. [...] That is what we know. And this is what differentiates us from them. It is the solidarity. It is the basis of all. [...] It is what we live here, and you will find nowhere. [...] Only here in Pikine, there is solidarity. I assure you, there is solidarity here.

DJIBRIL, Wakhinane II Quartier Mballo Der

Conclusion: Pikine Read by its Young Men

Situated at the margins of Dakar and therefore in many aspects fairly isolated from the economic activity of the capital city, the inhabitants of Pikine have managed to create different forms of self-organisations, which also foster various forms of urban self-identification and feelings of belonging. The most important notion among young men is Pikinité, which provides a feeling of solidarity, courage and local pride. As such, in recent years Pikine has seen a prolific emergence of small-scale initiatives and associations, and Pikine is today the origin of many musicians and sports stars. Pikinité offers Pikinois youth the opportunity to put their stamp on urban socialities and correct the unilateral and stigmatic image of Pikine. With recourse to antiquated values such as solidarity, the Pikinois bring their locality back into a discourse of village-like 
convictions, but at the same time they are deeply embedded in negotiations of participation and are actors of globalisation. While the first president of Senegal, Leopold Senghor, dreamed that Dakar would—in the year 2000-be like Paris, the question is no longer whether Dakar is like a European city, such as Paris or Berlin, or a North American city, like New York, but how the urban actors themselves experience urban realities and make them fit their needs, and how they negotiate global flows and might say 'We are from Pikine, but just as well we can be inhabitants of Paris or New York!' Through their choice of clothing, young men escape from grim economic realities; more specifically, they transform their outward appearance to convey symbolic representations of what they consider the successful self and to evoke feelings of global belonging (Scheld, 2007, 2008). However, this all is overshadowed by a challenging complex of problems embedded in very weak infrastructure, which includes annual floods and a lack of work opportunities for the young population.

During the administration of former president Abdoulaye Wade, Pikine was marginalised. Wade, with his urban-centric politics, fostered the development of certain urban neighbourhoods and initiated many flagship construction projects, especially ones that served his vision of Dakar as a 'showcase capital' and a global capital city (Melly, 2013, 2017). At the same time, he neglected many problem-afflicted parts of Dakar and failed to tackle the problems of Senegal's youth. In particular, many young men in Pikine felt excluded. An increasing gap between the rich and poor resulted from Wade's neo-liberal economic policy. This has made young males unite to speak out against rampant corruption and rising unemployment and has led to a growing mistrust of the government. It has created an awareness among young males that they are the architects of their own futures and that they cannot depend on the state for this. But this situation also impedes young men from advancing in their lives and becoming social adults who want to start a family and shoulder responsibility for themselves and their kin. However, even if these social conditions speak a very different language, the prevalent urban disorder should not per se be seen as negative; it is the precondition for the young men's spaces in which to manoeuvre.

To survive in this city, young male Pikinois show resourcefulness, embedded in an adapted competence for inventing coping strategies that might take surprising or even incomprehensible turns. They have equipped themselves with distinct identities and have cultivated the ability to inhabit the identity that a given occasion requires. Young men switch their identities depending on the situation-for example, a young man may be a pious Muslim in traditional raiment on a religious feast, or a Baay Faal wearing ragged motley garments known as Baye Lahat, or a Boy Town dressed up in fancy clothes in 
line with American trends on a Saturday evening. Thus, in line with Ferguson's 'performative competence' (1999, 104), young men in Pikine use their attire, consumption practices and also their speech and discursive practices to position themselves in different fields. This helps them to participate in processes of modernity and globalisation, to be in the world, not as passive spectators but as cosmopolitans with the ability to improvise and ultimately take part in building the nation.

\section{References}

Abbink, J. and I. Van Kessel (eds.) (2005) Vanguards or Vandals. Youth, Politics and Conflict in Africa (Leiden: Brill).

ANSD/SRSD (Agence Nationale de la Statistique et de la Démographie/Services Régionaux de la Statistique et de la Démographie) (2015) Situation Économique et Sociale régionale - 2013 (Dakar: ANSD).

Arieff, A. (2012) Senegal: Background and U.S. Relations (New York: CRS Congressional Research Service Reports on Foreign Policy and Regional Affairs).

Audrain, X. (2004) 'Devenir « Baay-fall » pour être soi: Le religieux comme vecteur d'émancipation individuelle au Sénégal'. Politique africaine, 94, pp. 149-165, DOI: 10.3917/polaf.094.0149.

Bahi, A. (2010) 'Jeunes et Imaginaire de la Modernité à Abidjan', Cadernos de Estudos Africanos, 18/19, pp. 56-67, DOI: 10.400o/cea.79.

Baller, S. (2010) Spielfelder der Stadt: Fusball und Jugendpolitik im Senegal seit $195^{\circ}$ (Köln: Böhlau).

Baller, S. (2007) 'Transforming Urban Landscapes: Soccer Fields as Sites of Urban Sociability in the Agglomeration of Dakar', African Identities, 5(2), pp. 217-230, DOI: 10.1080/14725840701403473.

Baller, S. (2005a) 'Urbane Zwischen-Räume. Jugendliche der banlieue von Dakar zwischen Lokalität und Globalität', in W. Speitkamp (ed.) Kommunikationsraume Erinnerungsraume. Beitrage zur transkulturellen Begegnung in Afrika (Munich: Meidenbauer), pp. 221-248.

Baller, S. $(2005$ b) 'Creating the Postcolonial City: Urban Youth Clubs in Senegal', in T. Falola and S.J. Salm (eds.) Urbanization and African Cultures (Durham, NC: Carolina Academic Press), pp. 139-153.

Bayart, J-F., A. Mbembe and C. Toulabor (eds.) (1992) Le Politique par le bas en Afrique noire. Contributions à une problématique de la démocratie (Paris: Karthala).

Benga, N. (2001) 'Entre Jérusalem et Babylon: jeunes et espace public à Dakar', Autrepart, 18, pp. 169-178, DOI: 10.3917/autr.018.0169. 
Biaya, T.K. (2001) 'Les plaisirs de la ville. Masculinité, sexualité et féminité à Dakar (1997-200o)', African Studies Review, 44(2), pp. 71-85, DOI: 10.2307/525575

de Boeck, F. and A.M. Honwana (eds.) (2005) Makers and Breakers. Children and Youth in Postcolonial Africa (Oxford: James Currey).

de Boeck, F. and M-F. Plissart (eds.) (2006) Kinshasa: Tales of the Invisible City (Antwerp: Ludion).

Chenal, J. (2013) La Ville Ouest-Africaine: Modèles de planification de l'éspace urbain (Geneva: MetisPresses).

Comaroff, J. and J. Comaroff (2000) 'Millennial Capitalism: First Thoughts on a Second Coming', Public Culture, 12(2), pp. 291-343, DOI: 10.1215/08992363-12-2-291.

Comaroff, J. and J. Comaroff (1999) 'Occult Economies and the Violence of Abstraction: Notes from the South African Postcolony', American Ethnologist, 26(2), pp. 279-303, DOI: 10.1525/ae.1999.26.2.279.

Cruise O'Brien, D.B. (1996) 'A Lost Generation? Youth Identity and State Decay in West Africa', in W. Richard and T. Ranger (eds.) Postcolonial Identities in Africa (London: Zed Books), pp. 55-74.

Diop, A. (2012) 'Dakar', in S. Bekker and G. Therborn (eds.) Capital Cities in Africa: Power and Powerlessness (Cape Town: HSRC Press), pp. 32-44.

Diouf, M. (2003) 'Engaging Postcolonial Cultures: African Youth and Public Space', African Studies Review, 46(2), pp. 1-12, DOI: 10.2307/1514823.

Diouf, M. (2002) 'Les jeunes Dakarois dans le champ politique', in M-C Diop, M. Diouf and D.B. Cruise O'Brien (eds.) La Construction de l'État au Sénégal (Paris: Karthala) pp. $157-167$.

Diouf, M. (1996) 'Urban Youth and Senegalese Politics. Dakar 1988-1994', Public Culture, 8(2), pp. 225-249, DOI: 10.1215/08992363-8-2-225.

Diouf, M. (1992) 'Fresques murales et écriture de l'histoire. Le Set/Setal à Dakar', Politique africaine, 46, pp. 41-54, http://politique-africaine.com/numeros/pdf/o46o41 .pdf (accessed on 22 April 2018).

Diouf, M. and R. Fredericks (2013) 'Introduction', in M. Diouf and R. Fredericks (eds.) Les arts de la citoyennete au Senegal: Espaces contestes et civilites urbaines (Paris: Karthala), pp. 11-44.

Durham, D. (2004) 'Disappearing youth: Youth as a social shifter in Botswana', American Ethnologist, 31(4), pp. 589-605, DOI: 10.1525/ae.2004.31.4.589.

Ferguson, J. (1999) Expectations of Modernity: Myths and Meanings of Urban Life on the Zambian Copperbelt (Berkeley, CA: University of California Press).

Galvan, D.C (2001) 'Political Turnover and Social Change in Senegal', Journal of Democracy, 12(3), pp. 51-62, DOI: 10.1353/jod.2001.0047.

Gilley, B. (2010) 'The end of the African renaissance', The Washington Quarterly, 33(4), pp. 87-101, DOI: 10.1080/016366oX.2010.516612. 
Grabski, J. (2017) Art World City: The Creative Economy of Artists and Urban Life in Dakar (Bloomington, IN: Indiana University Press).

Guibbert, J.-J. (1983) 'Symbols, Signs, Signals: Walls of the City', in B.B. Taylor (ed.) Reading the Contemporary African City (Singapore: Concept Media/Aga Khan Award for Architecture), pp. $75^{-84}$.

Havard, J.-F. (2001) 'Ethos «bul faale» et nouvelles figures de la réussite au Sénégal', Politique africaine, 82, pp. 63-77, DOI: 10.3917/polaf.082.0063.

Honwana, A.M. (2012) The Time of Youth: Work, Social Change, and Politics in Africa (Sterling, VA: Kumarian Press. Stylus Publishing).

de Jong, F. and V. Foucher (2010) 'La tragédie du roi Abdoulaye? Néomodernisme et Renaissance africaine dans le Sénégal contemporain', Politique africaine, 2, pp. 187-204, DOI: 10.3917/polaf.118.0187

Künzler, D. (2010) 'Des événements du Cabinda à la star Drogba: Les évolutions du football africain à l'aune de la Coupe du monde 2010', Afrique contemporaine, 233, pp. 15-24, DOI : 10.3917/afco.233.0015.

Le Soleil (2010) 'Interview avec Lahbib Ndiaye “L'homme sénégalais aime s’enrichir sans travailler"', Week-End. 13-14 Mars.

Lefebvre, H. (1967) Le droit à la ville (Paris: Éditions Anthropos).

Macpherson, C.B. (1962) The Political Theory of Possessive Individualism: Hobbes to Locke (Oxford: Oxford University Press).

Mané, M. (2012) Les valeurs culturelles des confréries musulmanes au Sénégal (Dakar: UNESCO), http://www.unesco.org/new/fileadmin/MULTIMEDIA/FIELD/Dakar/ pdf/EtudeconfreriesSenegal4Dec2012.pdf (accessed on 22 April 2018).

Myers, G. (2011) African Cities: Alternative visions of urban theory and practice (London/ New York: Zed Books).

Myers, G. and M. Murray (2007) 'Introduction: Situating Contemporary Cities in Africa', in Cities in Contemporary Africa (Basingstoke, UK: Palgrave Macmillan), pp. $1-25$.

Melly, C. (2017) Bottleneck: Moving, Building \& Belonging in an African City (Chicago, IL; London: The University of Chicago Press).

Melly, C. (2013) 'Ethnography on the Road: Infrastructural Vision and the Unruly Present in Contemporary Dakar', Africa: Journal of the International African Institute, 83(3), pp. 385-402, DOI: 10.1017/Sooo1972013000235.

Mustafa, H.N. (2001) 'Ruins and Spectacles: Fashion and City Life in Contemporary Senegal', Nka: Journal of Contemporary African Art, 15, pp. 47-53, DOI: 10.1215/10757163-15-1-47.

Ndjio, B. (2007) 'Douala: Inventing Life in an African Necropolis', in G.A. Myers and M.J. Murray (eds.) Cities in Contemporary Africa (Basingstoke, UK: Palgrave Macmillan), pp. 103-118. 
Nelson, S. (2014) 'The New Type of Senegalese under Construction: Fadel Barro and Aliou Sané on Yenamarrisme after Wade', African Studies Quarterly, 14(3), pp. 13-32, http://asq.africa.ufl.edu/files/Volume-14-Issue-3-Nelson.pdf (accessed on 22 April 2018).

Pezeril, C. (2008) Islam, Mysticisme et Marginalite: les Baay Faal du Senegal (Paris: L'Harmattan).

Pew Research Center (2013) The World's Muslims: Unity and Diversity, April 30, http:// www.pewforum.org/the-worlds-muslims (accessed on 5 June 2017).

Prause, L. (2012) 'Y'en a marre: Wer sind sie, wie mobilisieren sie und was fordern sie?' Standpunkte International, 2/2012, (Berlin: Rosa Luxemburg Stiftung), https://www .rosalux.de/publikation/id/5783/ (accessed on 22 April 2018).

Prothmann, S. (2017) 'Migration, masculinity and social class: Insights from Pikine, Senegal', International Migration, DOI: 10.1111/imig.12385.

Popovic, A. and G. Veinstein (1996) Les voies d'Allah: les ordres mystiques dans le monde musulman des origines a aujourd'hui (Paris: Fayard).

Ralph, M. (2008) 'Killing Time', Social Text 97, 26(4), pp. 1-29, DOI: 10.1215/016424722008-008.

Ritter, J.W.A. (2011) 'National Symbol or a National Frustration: Academic, Artistic, and Political Perspectives of the African Renaissance Monument', Independent Study Project (ISP) Collection. Paper 1200, http://www.digitalcollections.sit.edu/isp_collec tion/1200 (accessed on 5 June 2017).

Roberts, A.F. (2013) 'Citoyennetés visuelles en compétition dans le Sénégal contemporain', in M. Diouf and R. Fredericks (eds.) Les arts de la citoyennete au Senegal: Espaces contestes et civilites urbaines (Paris: Karthala), pp. 195-235.

Robinson, J. (2011) 'Cities in a World of Cities: The Comparative Gesture', International Journal of Urban and Regional Research, 35(1), pp. 1-23, DOI: 10.1111/j.1468-2427.2010.00982.x.

Salem, G. (1998) La sante dans la ville: Geographie d'un petit espace dense: Pikine (Senegal) (Paris: Karthala-Orstrom).

Savané, V. and B.M. Sarr (eds.) (2012) Y'en a marre: Radioscopie d'une jeunesse insurgée au Sénégal (Paris: Harmattan).

Scheld, S. (2007) 'Youth Cosmopolitanism: Clothing, the City and Globalization in Dakar, Senegal', City and Society, 19(2), pp. 232-253, DOI: 10.1525/city.2007.19. 2.232 .

Scheld, S. (2008) 'The City in a Shoe: redefining urban Africa through Sebago footwear consumption', City and Society, 15(1), pp. 109-130, DOI: 10.1525/city.2003.15.1.109.

Schimmel, A. (2011) Mystical Dimensions of Islam (Berkeley, CA: University of California Press).

Sene Absa, M. (2011) Yoole - Le Sacrifice (Dakar: Absa Films). 
Shipley, J.W. (2010) 'Self-Sovereignty and Creativity in Ghanaian Public Culture', in A.-M. Makhulu, B. Buggenhagen and S. Jackson (eds.) Hard Work, Hard Times: Global Volatility and African Subjectivities (Berkeley, CA: University of California Press), pp. 91-112.

Simone, A. (2010) 'Reaching a Larger World: Muslim Youth and Expanding Circuits of Operation', in A. Bayat and L. Herrera (eds.) Being Young and Muslim: New Cultural Politics in the Global South and North (New York: Oxford University Press), pp. $145^{-159 .}$

Osmanovic, A. (2017) "Sénégal Émergent”: State Building between Empire and Islam (Dakar: Rosa Luxemburg Stiftung West Africa). 